\title{
PENGEMBANGAN OBJEK WISATA PANTAI GANDORIAH KOTA PARIAMAN
}

\author{
Nur Putri Jayanti \\ Magister Administrasi Publik, Fakultas Ilmu Sosial, Universitas Negeri Padang, \\ nurputrijayanti1128@gmail.com
}

\begin{abstract}
ABSTRAK
Penelitian ini bertujuan untuk mengetahui pengembangan objek wisata Pantai Gandoriah Kota Pariaman, juga akan mengetahui kendala dalam melakukan pengembangan objek wisata Pantai Gandoriah Kota Pariaman, serta dapat memberikan solusi yang bisa ditawarkan kepada Dinas Pariwisata \& Kebudayaan Kota Pariaman. Jenis penelitian ini adalah Desktiptif Kualitatif dengan 3 teknik pengumpulan data yaitu observasi, wawancara, dan studi kepustakaan. Hasil penelitian mengungkapkan bahwa pengembangan objek wisata Pantai Gandoriah Kota Pariaman hingga saat ini sudah mulai membaik, dan sekarang pun Pemerintah Kota Pariaman sudah memiliki perencanaan yang matang dalam pengembangan objek wisata di masa depan yang akan dilakukan pada hierarki tingkat bawah yaitu desa.
\end{abstract}

Kata Kunci: Pariwisata, Pengembangan Pariwisata, Pantai Gandoriah

\begin{abstract}
This study aims to determine the development of Gandoriah Beach tourism object in Pariaman City, also to find out the obstacles in developing Gandoriah Beach tourism object in Pariaman City, and can provide solutions that can be offered to the Pariaman City Tourism \& Culture Office. This type of research is Desktiptif Qualitative with 3 techniques of data collection, namely observation, interview, and literature study. The results of the study revealed that the development of Gandoriah Beach tourism object in Kota Pariaman has started to improve until now, and now the Pariaman City Government already has careful planning in the development of tourism objects in the future which will be carried out at the lower level hierarchy, namely the village.
\end{abstract}

Keywords: Tourism, Tourism Development, Gandoriah Beach

\section{PENDAHULUAN}

Industri pariwisata merupakan sektor yang berpotensi dalam meningkatkan pendapatan daerah dan devisa negara. Manurut Eduardo (2018) sektor ini di prediksi akan jadi penyumbang devisa terbesar bagi Indonesia di 2018, yakni sebesar US\$ 20 miliar atau naik sekitar 20\% dari tahun 2017 yang sekitar US\$ 16,8 miliar. Data dari Website Resmi Kementerian Pariwisata menunjukkan bahwa angka wisatawan asing pada Tahun 2018 adalah sebesar 11.929.542 meningkat sekitar $11,61 \%$ dari tahun 2017.

Pariwisata merupakan sektor vital karena memiliki industri yang minim limbah, multiflyer effect, dan dapat mengembangkan potensi daerah. Pada beberapa tahun terakhir wisatawan meningkat yang berarti bahwa secara langsung meningkatkan pendapatan di bidang pariwisata. Pengembangan menurut Alim Sumarno (2012) adalah proses menterjemahkan atau menjabarkan spesifikasi rancangan ke dalam bentuk fitur fisik dengan pusat perhatian pada analisis kebutuhan juga isu-isu yang luas. Objek wisata adalah segala sesuatu yang ada di daerah tujuan wisata yang memiliki daya tarik agar orang-orang mau datang berkunjung ke tempat tersebut. Provinsi Sumatera Barat memiliki banyak potensi pariwisata daerah baik yang terletak di Kota

ISSN: 2355-6587, e-ISSN: 2528-2220

http://ejournal.bsi.ac.id/ejurnal/index.php/jp 
maupun yang ada di Kabupaten. Salah satunya adalah Kota Pariaman.

Kota Pariaman merupakan salah satu kota yang terletak di Provinsi Sumatera Barat dengan jarak $56 \mathrm{~km}$ dari Kota Padang. Melalui Portal Resmi Pemerintah Kota Pariaman, Kota Pariaman terbagi atas 4 Kecamatan, yaitu Kecamatan Pariaman Selatan, Kecamatan Pariaman Tengah, Kecamatan Pariaman Timur, dan Kecamatan Pariaman Utara, 55 Desa dan 16 Kelurahan yang jumlahnya tidak pernah berubah. Penduduk Kota Pariaman dalam Portal Resmi Kota Pariaman Tahun 2018 berjumlah 91.942 jiwa. Karena banyaknya penduduk Kota Pariaman, maka Dinas Pariwisata \& Kebudayaan (Disparbud) Kota Pariaman mengikutsertakan mereka dalam pengembangan objek wisata. Objek wisata di Kota Pariaman ada 3 yaitu wisata pantai, wisata alam, wisata budaya \& sejarah. Artikel ini akan membahas mengenai pengembangan objek wisata pantai, terkhusus wisata pantai gandoriah Kota Pariaman. Tujuan penulisan artikel ini meninjau sejauh mana pengembangan objek wisata pantai gandoriah Kota Pariaman sampai saat ini, apa kendala yang ditemui dan apa solusi dapat ditawarkan kepada Dinas Pariwisata \& Kebudayaan Kota Pariaman.

\section{KAJIAN LITERATUR \\ Pariwisata}

Menurut Suwantoro (dalam Rahmi, 2016:77) pariwisata adalah suatu proses perjalanan dari satu tempat ke tempat lain yang bersifat sementara dan di luar tempat tinggalnya, baik perorangan maupun kelompok. Pariwisata diadakan karena berbagai kepentingan, seperti kepentingan budaya, sosial, agama, atau kepentingan lainnya dengan tujuan untuk memperoleh kenikmatan serta memenuhi hasrat ingin mengetahui sesuatu. Sementara itu, orang atau kelompok yang mengadakan perjalanan disebut wisatawan, jika lama tinggalnya sekurang-kurangnya 24 jam di daerah atau tujuan wisata, tetapi jika lama tinggalnya dalam waktu kurang dari 24 jam disebut pelancong.

Yoeti (dalam Nandi, 2015:17) bahwa pariwisata adalah suatu perjalanan yang dilakukan untuk sementara waktu yang diselenggarakan dari suatu tempat ke tempat lain, dengan maksud bukan untuk berusaha atau mencari nafkah di tempat yang dikunjungi, tetapi sematamata untuk menikmati perjalanan tersebut guna bertamasya dan berekreasi untuk memenuhi keinginan yang beranekaragam. Perjalanan tersebut biasanya dilakukan untuk mencari suasana baru yang berbeda dengan suasana rutinitasnya sehari-hari dengan tujuan bermacam-macam, ada yang bertujuan beristirahat, mencari ketenangan atau bersenang-senang dan masih banyak lagi tujuan lainnya.

Berdasarkan pendapat di atas, maka pariwisata dapat diartikan sebagai kegiatan perpindahan dari satu tempat ke tempat lain dengan tujuan kepentingan di luar rutinitas sehar-hari yakni untuk bersenang-senang dan menikmati keindahan alam, ritual budaya, dan jenis kegiatan lainnya.

\section{Pengembangan Pariwisata}

Pengembangan pariwisata merupakan suatu rangkaian upaya untuk mewujudkan keterpaduan dalam penggunaan berbagai sumber daya pariwisata dan mengintegrasikan segala bentuk aspek di luar pariwisata yang berkaitan secara langsung maupun tidak langsung demi kelangsungan pengembangan pariwisata (Suwardjoko:2007). Terdapat beberapa jenis pengembangan, sebagai berikut: (1) keseluruhan dengan tujuan baru, seperti membangun atraksi di situs yang tadinya digunakan sebagai atraksi; (2) tujuan baru, seperti membangun atraksi pada situs yang sebelumnya telah digunakan sebagai atraksi; (3) pengembangan baru secara keseluruhan, seperti keberadaan atraksi yang dibangun untuk menarik pengunjung lebih banyak dan untuk membuat atraksi tersebut dapat mencapai pasar yang

ISSN: 2355-6587, e-ISSN: 2528-2220

http://ejournal.bsi.ac.id/ejurnal/index.php/jp 
lebih luas dengan meraih pasar yang baru; (4) pengembangan baru pada atraksi yang bertujuan untuk meningkatkan fasilitas pengunjung atau mengantisipasi meningkatnya pengeluaran sekunder oleh pengunjung; dan (5) penciptaan kegiatan-kegiatan baru atau tahapan dari kegiatan yang berpindah dari satu tempat ke tempat lain dimana kegiatan tersebut memerlukan modifikasi bangunan dan sruktur.

Menurut Yoeti (1996) ada tiga faktor yang dapat menentukan berhasilnya pengembangan pariwisata sebagai industri. Ketiga faktor tersebut sebagai berikut: (1) tersedianya objek wisata dan atraksi wisata yaitu segala sesuatu yang menjadi daya tarik bagi orang yang mengunjungi suatu daerah wisata. Misalnya keindahan alam, hasil kebudayaan, tata cara hidup masyarakat, festival tradisional maupun upacara keagamaan; (2) adanya accessibility yaitu prasarana dan sarana dengan segala fasilitas sehingga memungkinkan para wisatawan mengunjungi suatu daerah tujuan wisata tersebut; dan (3) tersedianya amenities yaitu sarana kepariwisataan yang dapat memberikan pelayanan kepada wisatawan selama dalam perjalanan wisata baik di dalam maupun di luar negeri.

\section{Pembangunan Kepariwisataan}

Undang-Undang Nomor 10 Tahun 2009 menyatakan bahwa Pemerintah dan Pemerintah Daerah mempunyai kewajiban dalam melakukan pembangunan kepariwisataan, sebagai berikut: (1) menyediakan informasi kepariwisataan, perlindungan hukum serta keamanan dan keselamatan kepada wisatawan; (2) menciptakan iklim yang kondusif untuk perkembangan usaha pariwisata yang meliputi terbukanya kesempatan yang sama dalam berusaha, memfasilitasi dan memberikan kepastian hukum; (3) memelihara dan mengembangkan serta melestarikan aset nasional yang menjadi daya tarik wisata dan aset potensial yang belum tergali; dan (4) mengawasi dan mengendalikan kegiatan kepariwisataan dalam rangka mencegah dan menanggulangi berbagai dampak negatif bagi masyarakat luas.

\section{Pantai Gandoriah}

Pantai Gandoriah merupakan pusat objek wisata Kota Pariaman, karena mudah dicapai dengan berbagai sarana transportasi, dan tempat transit ke objek wisata lainnya seperti ke pulau dan pantai lainnya. Untuk mencapai pantai ini, anda hanya perlu berjalan kaki dari Pasar Pariaman, atau naik kereta Api dari Kota Padang yang stasiunnya langsung di sekitar pantai ini. Sebelah Utara Pantai Gandoriah terdapat Muara Pantai Pariaman, ditempat ini wisatawan dapat menaiki Boat menuju ke 4 (empat) pulau yang ada di Kota Pariaman dengan sewa relatif murah yang telah dilengkapi dengan asuransi untuk masing-masing wisatawan.

Tak perlu khawatir dengan keselamatan keluarga anda, karena Pemerintah Kota Pariaman melalui Badan Penanggulangan Bencana Daerah (BPBD) juga menyediakan petugas "Safe Guard" yang mengawasi dengan perahu karet berpatroli disepanjang bibir pantai. Sekitar pantai, ada salah satu transportasi tradisional yang masih bisa kita temui di Pariaman yaitu Bendi. Hamparan pasirnya yang luas, banyak dimanfaatkan warga untuk berbagai aktivitas seperti family gathering, senam, sepak bola, voli pantai, bermain layangan atau berselancar, karena ada klub surfing yang berposko di pantai ini (Sumber: Website Resmi Pariaman Visit).

\section{Visi Misi Kota Pariaman}

Visi dan Misi Kota Pariaman bisa dilihat secara online melalui Website Resmi Pemerintah Kota Pariaman. Visi dan misinya sebagai berikut:

VISI : "Pariaman Kota Wisata, Perdagangan, Jasa Yang Religius Dan Berbudaya"

MISI :

Tabel 1

Misi Kota Pariaman

1. Mewujudkan pengelolaan wisata kota

ISSN: 2355-6587, e-ISSN: 2528-2220

http://ejournal.bsi.ac.id/ejurnal/index.php/jp 
yang maju, religius, tertib dan berbudaya

2. Mewujudkan kehidupan masyarakat yang berbudaya dan berkualitas

3. Mewujudkan pemerintah yang andal dan prima untuk meningkatkan kualitas pelayanan publik

4. Mewujudkan kota pesisir modern, dinamis, dan berwawasan lingkungan

5. Memperkuat ekonomi kerakyatan (kreatif) yang berbasis lokal dan budaya masyarakat

Sumber:https://www.pariamankota.go.id

\section{METODE PENELITIAN}

Penelitian ini merupakan jenis penelitian deskriptif kualitatif yang memberikan hasil penelitian dalam bentuk uraian kualitatif, mereduksi kesimpulan berdasarkan data-data yang dilakukan dengan 3 teknik pengumpulan data yaitu: Pertama observasi atau pengamatan yang dilakukan langsung ke objek wisata pantai gandoriah tersebut bersama-sama. Melihat keadaan langsung yang terjadi mengenai pengembangan objek wisata tersebut. Observasi lapangan dilakukan pada tanggal 15 Desember 2018. Kedua wawancara dilakukan dengan Kepala Dinas Pariwisata \& Kebudayaan Kota Pariaman yang bernama Bapak Elfiswandi dan Walikota Pariaman yang bernama Bapak Genius Umar yang dilaksanakan pada tanggal 18 Desember 2018. Ketiga studi kepustakaan dilakukan dengan data-data yang ada di Portal dan Website Resmi Pemerintah Kota Pariaman maupun Dinas Pariwisata \& Kebudayaan Kota Pariaman serta Kementerian Pariwisata Republik Indonesia.

PEMBAHASAN

Pengembangan Objek Wisata Pantai Gandoriah Kota Pariaman

Berdasarkan hasil wawancara dengan Kepala Dinas Pariwisata \& Kebudayaan Kota Pariaman Bapak Elfiswandi dijelaskan bahwa Kota Pariaman merupakan kawasan strategis wisata mulai dari Pantai Sunur sampai Pantai Belibis, dari 5 pulau yang di miliki Kota Pariaman 2 pulau diantaranya sudah dilakukan penataan atau pengelolaan seperti pengadaan sarana dan prasarana, infrastruktur serta memfasilitasi pelakupelaku usaha beraktivitas di destinasi wisata dalam rangka memberikan kepuasan kepada pengunjung yang datang. Untuk menuju pulau tersebut maka pengunjung harus menuju pantai gandoriah terlebih dahulu, karena darmaga atau penghubungnya ada di pantai tersebut.

Tujuan adanya pengembangan dan pengelolaan pariwisata di pantai gandoriah adalah agar masyarakat bisa beraktivitas secara ekonomi dalam rangka peningkatan kesejahteraan hidup pelaku usaha di destinasi wisata. Beberapa tahun belakangan ini sudah dilakukan penataan, pengelolaan dan pengembangan di kawasan wisata pantai gandoriah, dan dapat dilihat saat ini bahwa sudah banyak terlihat wahana yang dapat di naiki baik oleh orang dewasa hingga anak-anak serta juga ada wahana air yang terjamin safetynya oleh Dinas Pariwisata \& Kebudayaan Kota Pariaman.

Pengembangan pariwisata selanjutnya tidak hanya berpusat di daerah pesisir melainkan juga dikembangkan di kecamatan, desa dan kelurahan lainnya dalam bentuk Konsep Waterproof City atau daerah pinggiran sungai akan dilakukan penataan secara infrastruktur dan hal-hal lainnya yang mendukung keindahan daerah sungai hingga menarik para wisatawan untuk mengunjunginya. Selanjutnya pengembangan dilakukan di wilayah selatan kemudian ke wilayah utara. Pada kecamatan pariaman timur dilakukan pengembangan konsep wisata bernuansa alami. Sehingga agar hal itu terlaksana maka diperlukan kerjasama dari seluruh pihak, tidak hanya bertumpu pada satu dinas saja. Seluruh sektor harus bergerak membangun pariwisata, hal inilah yang akan ditingkatkan. 


\section{Kendala Pengembangan Objek Wisata Pantai Gandoriah Kota Pariaman}

Adanya pengembangan objek wisata maka tidak terlepas dari kendala yang di hadapi dalam pengembangan objek wisata pantai gandoriah Kota Pariaman, berdasarkan hasil wawancara ditemukan beberapa hal yang dianggap sebagai kendala dalam pengembangan objek wisata pantai, sebagai berikut: (1) Lahan. Tanah di sekitar pantai Gondoriah, tanah masih berstatus sebagai tanah ulayat dan tanah nagari. Hal ini membuat pengembangan pariwisata Gondoriah agak terhambat karena untuk pembebasan lahan membutuhkan waktu dan biaya serta prosedur yang rumit; (2) Perizinan. Untuk membangun infrastruktur diperlukannya izin dari dinas terkait, seperti izin pengelolaan lingkungan, izin perhubungan dan AMDAL di tempat wisata tersebut; dan (3) Perilaku Masyarakat. Konsep pembangunan pariwisata salah satunya adalah sapta pesona yaitu bersih, indah, tertib, aman, kenangan dan ramah tamah. Sapta pesona ini belum diterapkan oleh masyarakat, terutama perilaku pelaku usaha di tempat wisata. Kota pariaman dalam pengembangan objek wisata membutuhkan waktu dalam merubah minset atau perilaku masyarakat. Menurut hasil wawancara perilaku pelaku industri pariwisata seperti pedagang, masyarakat sekitar dan petugas parkir di kawasan Pantai Gondoriah menunjukkan perilaku kurang senyum, tidak ramah, dan sebagian yang tidak menjaga kebersihan wilayah pantai.

Solusi Ditawarkan Kepada Dinas Pariwisata \& Kebudayaan Kota Pariaman

Berdasarkan beberapa kendala dalam pengembangan objek wisata Pantai Gandoriah di Kota Pariaman, kami memberikan beberapa solusi alternative yang dapat ditawarkan kepada Dinas Pariwisata \& Kebudayaan Kota Pariaman, sebagai berikut: (1) Lakukan sosialisasi. Sosialisasi dapat dilakukan kepada setiap aturan, pandangan dan pola pikir pemerintah yang disalurkan kepada masyarakat agar mereka paham dan mengerti maksud dan tujuan pemerintah melakukan suatu kegiatan, terutama dalam hal pembangunan objek wisata pantai; (2) Libatkan peran aktif masyarakat. Libatkan masyarakat dalam segala bentuk pembangunan, penataan, dan pengembangan yang berhubungan dengan objek wisata pantai. Berikan kepercayaan kepada mereka untuk dapat ikut terlibat dalam pengelolaan kawasan wisata; (3) Penambahan Atraksi Pariwisata. Seperti memajang Gallery Oleh-Oleh Khas Pariaman seperti makanan tradisional dan hasil kerajinan di sepanjang jalan dekat parkir pantai Gondoriah dan pemajangan brosur informasi pariwisata di pintu masuk. Brosur informasi ini sebaiknya membahas tentang atraksi wisata lain yang terdapat di Kota Pariaman serta akomodasi yang tersedia dan transportasi untuk mencapai objek wisata yang ditawarkan; dan (4) Pelatihan Sapta Pesona. Selain itu sebaiknya diadakan pelatihan sapta pesona kepada pelaku pariwisata yang terlibat agar pelayanan pariwisata lebih ramah, sehingga membuat wisatawan menjadi nyaman melakukan kegiatan wisata.

Jika solusi alternative ini dapat diterapkan maka kendala yang ditimbulkan bisa diminimalisir. Solusi ini bisa dijadikan rujukan bagi Pemerintah Kota disamping rencana strategis Dinas Pariwisata \& Kebudayaan Kota Pariaman yang telah di buat.

\section{PENUTUP}

Kegiatan pariwisata tidak terlepas dari atraksi dan fasilitas yang ditawarkan oleh lokasi wisata. Sektor pariwisata akan berkembang jika pengelolaan destinasi dilakukan secara berkesinambungan dan pelayanan yang diberikan tepat guna. Pantai Gondoriah merupakan destinasi pariwisata andalan

ISSN: 2355-6587, e-ISSN: 2528-2220

http://ejournal.bsi.ac.id/ejurnal/index.php/jp 
di Kota Pariaman yang di dukung oleh transportasi yang lancar dan fasilitas yang mulai berkembang, meski beberapa fasilitas masih berada dalam tahap pembangunan. Komitmen pemerintah khususnya Dinas Pariwisata \& Kebudayaan Kota Pariaman sangat diperlukan dalam pengelolaan agar wilayah Pantai Gondoriah dapat menarik minat wisatawan dan meningkatkan pendapatan asli daerah (PAD).

Sejauh ini, pengembangan objek wisata Pantai Gandoriah Kota Pariaman sudah membaik bahkan perencanaan ke depan pun Pemerintah Kota sudah memikirkan pengembangan yang dilakukan lebih pada ke hierarki tingkat bawah yaitu desa. Pada tingkat inilah, nanti akan dilakukan pengembangan objek wisata di sekitaran sungai. Konsep pariwisata di Kota Pariaman ini diharapkan menjadi berbasis masyarakat. Pengunjung kawasan wisata tahun ke tahun sudah mulai meningkat, terbukti pada tahun 2017 total pengunjung sebanyak 3,1 juta jiwa, sedangkan tahun sebelumnya hanya 300 atau 400 ribu jiwa.

\section{REFERENSI}

Nandi. 2015. Memaksimalkan Potensi Wisata Alam di Jawa Barat. Jurnal Manajemen Riset dan Leisure, Vol.1, No.1.

Portal Resmi Pariaman Visit (Online) https://visitpariaman.com.

P, Suwardjoko \& Indra P. 2007. Pariwisata Dalam Tata Ruang Wilayah. Bandung: ITB.
Rahmi, Siti Atika. 2016. Pembangunan

Pariwisata dalam Perspektif

kearifan Lokal. Jurnal

Reformasi, Vol.6, No.1.

Simorangkir, Eduardo. 2018. Pariwisata Jadi Andalan Penyumbang

Devisa US\$ 20 Miliar. Berita

DetikFinance (Online)

https://finance.detik.com.

Sumarno, Alim. 2012. Penelitian Kausalitas Komparatif. Surabaya: Elearning Unesa.

Undang-Undang Republik Indonesia Nomor 10 Tahun 2009 Tentang Kepariwisataan.

Wawancara dengan Bapak Elfiswandi. Kepala Dinas Pariwisata \& Kebudayaan Kota Pariaman. Pada tanggal 18 Desember 2018.

Wawancara dengan Bapak Genius Umar. Walikota Pariaman. Pada tanggal 18 Desember 2018.

Website Resmi Kementerian Pariwisata Republik Indonesia (Online) www.kemenpar.go.id.

Website Resmi Pemerintah Kota Pariaman (Online) https://www.pariamankota.go.id.

Yoeti. 1996. Pengantar Ilmu Pariwisata. Bandung: Angkasa.

\section{BIODATA PENULIS}

Nur Putri Jayanti, lahir di Padang Tanggal 28 Nopember 1996. Menyelesaikan S1 Pada Jurusan Administrasi Publik, Fakultas Ilmu Sosial, Universitas Negeri Padang Tahun 2018. Lalu Melanjutkan Pendidikan S2 Pada Program Magister Administrasi Publik, Fakultas Ilmu Sosial, Universitas Negeri Padang. 